\section{Epidemiological, clinical and histological aspects of cutaneous melanoma of the head and neck region}

\author{
Thiago Demétrio Nogueira Costa e Silva ${ }^{1 *}$, \\ Emidiana Raquel Rodrigues de Souza Oliveira², Sheila Maria da Conceição Costa², \\ Cláudia Isabel Silva Carlos², Karla Regina Figueirôa Batista ${ }^{3}$
}

\begin{abstract}
Introduction: Melanoma accounts for only $4 \%$ skin malignancies, but its incidence has been increasing in recent decades. In addition, it has the worst prognosis and high mortality rate. Objective: To trace the clinical, epidemiological and histological profile of patients with melanoma. Materials and Methods: A retrospective and observational study was carried out through the charts of patients with the disease attended at the Center of Oncology and Hematology of Mossoró from 2006 to 2015. Results: There was a predominance of women (56.7\%), with a mean age of 60.7 years, Caucasian people (61.0\%), incomplete elementary school (62.0\%), farmers (38.8\%) and no history of cancer in the family (62.5\%). The main complaint was the presence of elementary lesion (79.3\%), which in most cases was in the trunk (38.8\%) at an advanced stage (52.6\%). The predominant lesion was extensive superficial melanoma (47.8\%), with Breslow below $1 \mathrm{~mm}$ (28.2\%) or above $4 \mathrm{~mm}$ (28.2\%), Clark IV (48.7\%), with ulceration (65\%), but without angiolymphatic (83.3\%) or perineural (95.8\%) invasion. The treatment, in most cases, was surgical (71.7\%). Regarding the survival, the average time of death of patients was 668.8 days. The mortality rate was $31.7 \%$. Conclusion: The pattern found was similar to other studies, except for the variables of age and Clark level.
\end{abstract}

Keywords: skin neoplasms; melanoma; health profile; survival analysis.

Financial support: None. Conflicts of interest: No conflicts of interest declared concerning the publication of this article. Submitted: November 05, 2017. Accepted: June 22, 2018.

The study was carried out at Universidade Federal Rural do Semi-Árido (UFERSA), Mossoró, RN, Brasil.

Copyright Costa e Silva et al. This is an Open Access article distributed under the terms of the Creative Commons Attribution License, which permits unrestricted use, distribution, and reproduction in any medium, provided the original work is properly cited.

\section{Introduction}

Skin cancer is the most prevalent in Brazil, corresponding to $25 \%$ of the malignant neoplasias registered in the country. It can be classified into melanoma and non-melanoma, depending on the kind of cell affected. Melanoma originates in the melanocytes, cells that produce melanin and corresponds only to $4 \%$ of skin malignant neoplasias. However, it has the worst prognosis and presents high mortality rate ${ }^{1}$.

The incidence of cutaneous melanoma is growing in many parts of the world ${ }^{2}$. According to the National Cancer Institute (Instituto Nacional do Câncer - INCA), the estimative for 2016 in Brazil is of 5,670 cases, being 3,000 men and 2,670 women ${ }^{3}$.

Melanoma usually affects individuals of both genders that have light skin, hair and eyes (phototypes I and II, according to Fitzpatrick's classification), 
after 50 years old ${ }^{4,5}$. It prevails in the Southern and Southeastern regions of Brazil, where are concentrated most studies in the area. In the Northern and Northeastern regions, the studies about this are scarce ${ }^{5}$.

The main risk factor is the excessive exposure to ultraviolet radiation. The presence of premalignant lesions (dysplastic nevus, actinic keratosis etc.) and the exposure to artificial tanning are also considered as predisposing factors. In addition, mutation in the CDKN2A, CDK4 27 and XPC 23 genes can be responsible for additional risk ${ }^{5-7}$.

The diagnosis is essentially clinic, given from the identification of the characteristic lesion: asymmetry (A), jagged or poorly defined edges (B), mixed color (C), diameter > $6 \mathrm{~mm}(\mathrm{D})$, called the "ABCD" criteria. The biopsy followed by the histopathological exam is essential for diagnostic confirmation and for treatment schedule1.

The treatment is usually the surgical resection with appropriate margins, with a good cure rate for the initial cases, which involve only the superficial layer of the skin. The surgical modality depends on the extent, aggression and location of the tumor, being excisional surgery and Mohs micrographic surgery the most employed. In recent years, there has been an increase in the detection of in situ melanoma, mainly due to new technologies such as dermatoscopy and the dissemination of information on the characteristics of the disease' 1 .

Despite diagnostic and therapeutic advances, melanoma is still the most lethal skin cancer, with common presence of metastasis. In metastatic cases, the prognosis is not favorable, and there is no cure in most cases, being the treatment options limited. When distant metastases are present, the 5 -year life rates are less than $10 \%$. Hence the importance of early diagnosis ${ }^{8,9}$. The objective of the study was to trace the clinical, epidemiological and histological profile of melanoma patients in a 10-year period.

\section{Methods}

The research project was approved by the Ethics and Research Committee of the Rio Grande do Norte State University under 1.981.048.

A retrospective and observational study was carried out in which patients diagnosed with melanoma were evaluated at Mossoró Oncology and Hematology Center (COHM) in a period of 10 years (2006 to 2015) through analysis of Medical records. Information on the date of death and cause of death were acquired by means of the Mortality Information System (Sistema de Informação sobre Mortalidade - SIM).

All patients diagnosed with melanoma (confirmed by histopathological examination) were included in the research in the period covered by the study. Patients with synchronous tumors, those who possessed unsatisfactory medical records and those who lost medical follow-up were excluded from the study.

The analyzed variables included sociodemographic (gender, age, degree of schooling, occupation, origin), clinical (initial sign/symptom, location, size, presence of lymph node or distant metastases, metastasis localization, staging and treatment) and histopathological aspects (histological type, Breslow, 
Clark, ulceration, angiolymphatic and perineural invasions), as well as risk factors (family history).

Tumor staging (TNM) was defined according to the norms established by the American Joint Committee on Cancer (AJCC) and Union for International Cancer Control (UICC) for classification of malignant tumors ${ }^{10}$.

The data were analyzed by exploratory descriptive statistics using the Microsoft Excel Program ${ }^{\circledR}$, version 2010 and SPSS ${ }^{\circledR}$, version 20.0. A bivariate analysis (CHI-squared test) was performed to determine the association among the variables. For the survival time, defined as the time (in months) between the diagnosis of the disease and the death, a surviving analysis was made by the Kaplan-Meier method. For all statistical procedures, a 5\% significance level was adopted.

\section{Results}

60 records of melanoma patients attended between 2006 and 2015 (10 years) were analyzed. In Table 1, the patient's demographic profile is described.

Table 1. Social-demographic profile.

\begin{tabular}{|c|c|c|c|}
\hline \multicolumn{2}{|c|}{ Characteristics } & \multirow{2}{*}{$\begin{array}{c}\text { Frequency } \\
26\end{array}$} & \multirow{2}{*}{$\begin{array}{c}\% \\
43.3 \\
\end{array}$} \\
\hline Gender & Male & & \\
\hline sernuer & Female & 34 & 56.7 \\
\hline \multirow{8}{*}{ Age group } & $10-19$ & 1 & 1.7 \\
\hline & $20-29$ & 1 & 1.7 \\
\hline & $30-39$ & 2 & 3.3 \\
\hline & $40-49$ & 10 & 16.7 \\
\hline & $50-59$ & 12 & 20.0 \\
\hline & $60-69$ & 19 & 31.7 \\
\hline & $70-79$ & 9 & 15.0 \\
\hline & $80-89$ & 6 & 10.0 \\
\hline \multirow{3}{*}{ Race/skin color } & White & 36 & 61.0 \\
\hline & Brown & 19 & 32.2 \\
\hline & Black & 4 & 6.8 \\
\hline \multirow{5}{*}{ Degree of schooling* } & Illiterate & 3 & 10.3 \\
\hline & Incomplete Elementary School & 18 & 62.0 \\
\hline & Complete Elementary School & 1 & 3.4 \\
\hline & High School & 3 & 10.3 \\
\hline & College degree & 4 & 13.8 \\
\hline \multirow{7}{*}{ Occupation ${ }^{*}$} & Farmer & 19 & 38.8 \\
\hline & Housewife & 7 & 14.3 \\
\hline & Trader & 3 & 6.1 \\
\hline & Mason & 3 & 6.1 \\
\hline & Teacher & 2 & 4.1 \\
\hline & Other & 15 & 30.6 \\
\hline & Total & 60 & 100.00 \\
\hline
\end{tabular}

*Partially absent data. 
As for gender, most of the patients were women (56.7\%). The age of the patients varied from 15 to 87 years, being the average age 60.4 years, with standard deviation of 14.8 and predominance of the age range of 60 to 69 years. The majority was Caucasian (61.0\%) and agriculture was the predominant occupation (38.8\%). As for the family history, the only risk factor researched, $23.1 \%$ of the patients had at least one relative with cancer in the family.

Table 2 depicts the clinical profile of the patient with melanoma. As for the main complaint of the patients at the time of the first consultation in the hospital, $79.3 \%$ sought the doctor due to an elementary injury, whereas $11 \%$ of patients had as main complaint lymphadenomegaly.

Table 2. Clinic profile.

\begin{tabular}{|c|c|c|c|}
\hline \multicolumn{2}{|c|}{ Characteristics } & \multirow{2}{*}{$\begin{array}{c}\text { Frequency } \\
25\end{array}$} & \multirow{2}{*}{$\begin{array}{c}\% \\
42.4\end{array}$} \\
\hline \multirow{5}{*}{$\begin{array}{l}\text { Medical specialty in the } \\
\text { first attendance }\end{array}$} & Clinical oncology & & \\
\hline & Surgical oncology & 24 & 40.7 \\
\hline & HNS & 7 & 11.9 \\
\hline & Neurosurgery & 2 & 3.4 \\
\hline & Mastology & 1 & 1.7 \\
\hline \multirow{3}{*}{ Initial sign or symptom* } & Elementary injury & 46 & 79.3 \\
\hline & Lymphoedema & 11 & 19.0 \\
\hline & Unilateral epistaxis & 1 & 1.7 \\
\hline \multirow{4}{*}{ General location* } & Trunk & 19 & 38.8 \\
\hline & Inferior limb & 16 & 32.6 \\
\hline & Head and neck & 9 & 18.4 \\
\hline & Superior limb & 5 & 10.2 \\
\hline \multirow{18}{*}{ Specific location* } & Back & 14 & 23.7 \\
\hline & Sole & 6 & 10.2 \\
\hline & Thigh & 5 & 8.5 \\
\hline & Ear & 4 & 6.8 \\
\hline & Thorax & 4 & 6.8 \\
\hline & Forearm & 2 & 3.4 \\
\hline & Toe & 2 & 3.4 \\
\hline & Nose & 2 & 3.4 \\
\hline & Leg & 2 & 3.4 \\
\hline & Abdomen & 1 & 1.6 \\
\hline & Arm & 1 & 1.6 \\
\hline & Scalp & 1 & 1.6 \\
\hline & Finger & 1 & 1.6 \\
\hline & Back of the hand & 1 & 1.6 \\
\hline & Back of the foot & 1 & 1.6 \\
\hline & Face & 1 & 1.6 \\
\hline & Neck & 1 & 1.6 \\
\hline & Unknown & 10 & 17.0 \\
\hline
\end{tabular}

*Partially absent data. 
Table 2. Continued...

\begin{tabular}{|c|c|c|c|}
\hline \multicolumn{2}{|c|}{ Characteristics } & \multirow{2}{*}{$\begin{array}{c}\text { Frequency } \\
12\end{array}$} & \multirow{2}{*}{$\begin{array}{c}\% \\
22.2\end{array}$} \\
\hline \multirow{5}{*}{ Injury size $(T)^{\star}$} & $\mathrm{T} 1$ & & \\
\hline & $\mathrm{T} 2$ & 8 & 14.8 \\
\hline & T3 & 9 & 16.7 \\
\hline & $\mathrm{T} 4$ & 15 & 27.8 \\
\hline & $\mathrm{TX}$ & 10 & 18.5 \\
\hline \multirow{5}{*}{$\begin{array}{l}\text { Lymph node metastasis } \\
(\mathrm{N})^{\star}\end{array}$} & No & 29 & 51.8 \\
\hline & N1 & 8 & 14.3 \\
\hline & $\mathrm{N} 2$ & 12 & 21.4 \\
\hline & N3 & 1 & 1.8 \\
\hline & $N X$ & 6 & 10.7 \\
\hline \multirow{3}{*}{ Distant metastasis (M)* } & M0 & 38 & 64.4 \\
\hline & M1 & 17 & 28.8 \\
\hline & $\mathrm{MX}$ & 4 & 6.8 \\
\hline \multirow{5}{*}{ Metastasis location* } & Lung & 5 & 33.3 \\
\hline & Distant lymph node & 4 & 26.7 \\
\hline & Nervous system & 4 & 26.7 \\
\hline & Liver & 2 & 13.3 \\
\hline & Parotid gland & 2 & 13.3 \\
\hline \multirow{5}{*}{ Stage* } & I & 14 & 24.6 \\
\hline & II & 13 & 22.8 \\
\hline & III & 12 & 21.0 \\
\hline & IV & 18 & 31.6 \\
\hline & Total & 60 & 100.00 \\
\hline
\end{tabular}

*Partially absent data.

The dominant location was the trunk (38.8\%), followed by the lower limbs (32.6\%). In women, they dominated the lower limbs (35.7\%) and the trunk (35.7\%), followed by the upper limbs (17.9\%) and in the men dominated the trunk (42.8\%), followed by the lower limbs (28.6\%), and head and neck (28.6\%).

The lesion size ranged from 0.5 to $9 \mathrm{~cm}$, with an average of $2.2 \mathrm{~cm}$ and median of $2 \mathrm{~cm}$. Most lesions were bigger than $6 \mathrm{~mm}$, following the ABCD rule.

Regarding metastasis to lymph nodes, $37.5 \%$ of patients presented lymphatic metastasis. The distant metastasis was present in $28.8 \%$ of the patients. The cases in advanced stage (III and IV) were predominant (52.6\%).

Applying the chi-squared (X2) test or Fischer's exact test in the death rate with the patients characteristics (Table 3), for a 5\% significance level, there is statistic evidence of the death with age and stadium, so the patients older than 60 years and with advanced stage (III and IV) showed higher death rate.

Table 4 describes the histological profile of the lesions. The most prevalent histologic subtype was the superficial extensive (47.8\%), followed by nodular 
Table 3. Death rate versus patient characteristics.

\begin{tabular}{|c|c|c|c|c|c|}
\hline \multirow{2}{*}{\multicolumn{2}{|c|}{ Patient characteristics }} & \multicolumn{2}{|c|}{ Death } & \multirow{2}{*}{ Total } & \multirow{2}{*}{ Value-p } \\
\hline & & Yes & No & & \\
\hline \multirow{2}{*}{ Gender } & Male & $46.15 \%(n=12)$ & $53.85 \%(n=14)$ & $100.00 \%(n=26)$ & \multirow{2}{*}{$0.276^{(1)}$} \\
\hline & Female & $32.35 \%(n=11)$ & $67.65 \%(n=23)$ & $100.00 \%(n=34)$ & \\
\hline \multirow{2}{*}{ Age group } & Until 60 years & $21.43 \%(n=6)$ & $78.57 \%(n=22)$ & $100.00 \%(n=28)$ & \multirow{2}{*}{$0.012^{(1)}$} \\
\hline & Over 60 years & $53.13 \%(n=17)$ & $46.88 \%(n=15)$ & $100.00 \%(n=32)$ & \\
\hline \multirow{2}{*}{ Family history } & No & $40.00 \%(n=8)$ & $60.00 \%(n=12)$ & $100.00 \%(n=20)$ & \multirow{2}{*}{$1.000^{(2)}$} \\
\hline & Yes & $50.00 \%(n=3)$ & $50.00 \%(n=3)$ & $100.00 \%(n=6)$ & \\
\hline \multirow{2}{*}{ Surgery } & No & $52.94 \%(n=9)$ & $47.06 \%(n=8)$ & $100.00 \%(n=17)$ & \multirow{2}{*}{$0.143^{(1)}$} \\
\hline & Yes & $32.56 \%(n=14)$ & $67.44 \%(n=29)$ & $100.00 \%(n=43)$ & \\
\hline \multirow{2}{*}{ Immunotherapy } & No & $33.33 \%(n=16)$ & $66.67 \%(n=32)$ & $100.00 \%(n=48)$ & \multirow{2}{*}{$0.183^{(2)}$} \\
\hline & Yes & $58.33 \%(n=7)$ & $41.67 \%(n=5)$ & $100.00 \%(n=12)$ & \\
\hline \multirow{2}{*}{ Chemotherapy } & No & $34.69 \%(n=17)$ & $65.31 \%(n=32)$ & $100.00 \%(n=49)$ & \multirow{2}{*}{$0.306^{(2)}$} \\
\hline & Yes & $54.55 \%(n=6)$ & $45.45 \%(n=5)$ & $100.00 \%(n=11)$ & \\
\hline \multirow{2}{*}{ Stage } & I and II & $22.22 \%(n=6)$ & $77.78 \%(n=21)$ & $100.00 \%(n=27)$ & \multirow{2}{*}{$0.008^{(1)}$} \\
\hline & III and IV & $56.67 \%(n=17)$ & $43.33 \%(n=13)$ & $100.00 \%(n=30)$ & \\
\hline \multirow{4}{*}{ General location } & Trunk & $15.79 \%(n=3)$ & $84.21 \%(n=16)$ & $100.00 \%(n=19)$ & \multirow{4}{*}{$0.062^{(1)}$} \\
\hline & Inferior limbs & $31.25 \%(n=5)$ & $68.75 \%(n=11)$ & $100.00 \%(n=16)$ & \\
\hline & Head and neck & $66.67 \%(n=6)$ & $33.33 \%(n=3)$ & $100.00 \%(n=9)$ & \\
\hline & Superior limbs & $40.00 \%(n=2)$ & $60.00 \%(n=3)$ & $100.00 \%(n=5)$ & \\
\hline \multirow{4}{*}{ Breslow* } & Until $1 \mathrm{~mm}$ & $18.18 \%(n=2)$ & $81.82 \%(n=9)$ & $100.00 \%(n=11)$ & \multirow{4}{*}{$0.576^{(1)}$} \\
\hline & $1.01-2.00 \mathrm{~mm}$ & $42.86 \%(n=3)$ & $57.14 \%(n=4)$ & $100.00 \%(n=7)$ & \\
\hline & $2.01-4.00 \mathrm{~mm}$ & $20.00 \%(n=2)$ & $80.00 \%(n=8)$ & $100.00 \%(n=10)$ & \\
\hline & Over $4.00 \mathrm{~mm}$ & $36.36 \%(n=4)$ & $63.64 \%(n=7)$ & $100.00 \%(n=11)$ & \\
\hline \multirow{5}{*}{ Histological type* } & Superficial extensive & $27.27 \%(n=6)$ & $73.73 \%(n=16)$ & $100.00 \%(n=22)$ & \multirow{5}{*}{$0.186^{(1)}$} \\
\hline & Nodular & $41.70 \%(n=5)$ & $58.30 \%(n=7)$ & $100.00 \%(n=10)$ & \\
\hline & Malignant lentigo & $0.00 \%(n=0)$ & $100.00 \%(n=5)$ & $100.00 \%(n=5)$ & \\
\hline & Accra-lentiginous & $40.00 \%(n=2)$ & $60.00 \%(n=3)$ & $100.00 \%(n=5)$ & \\
\hline & Metastatic & $50.00 \%(n=1)$ & $50.00 \%(n=1)$ & $100.00 \%(n=2)$ & \\
\hline \multirow{2}{*}{ Clark* } & I, II and II & $30.77 \%(n=4)$ & $69.23 \%(n=9)$ & $100.00 \%(n=13)$ & \multirow{2}{*}{$1.000^{(2)}$} \\
\hline & IV and V & $33.33 \%(n=8)$ & $66.67 \%(n=16)$ & $100.00 \%(n=24)$ & \\
\hline \multirow{2}{*}{ Ulceration* } & No & $42.86 \%(n=3)$ & $57.14 \%(n=4)$ & $100.00 \%(n=7)$ & \multirow{2}{*}{$1.000^{(2)}$} \\
\hline & Yes & $38.46 \%(n=5)$ & $61.54 \%(n=8)$ & $100.00 \%(n=13)$ & \\
\hline Angiolymphatic & Absent & $25.00 \%(n=5)$ & $75.00 \%(n=15)$ & $100.00 \%(n=20)$ & 0552 (2) \\
\hline invasion* & Present & $50.00 \%(n=2)$ & $50.00 \%(n=2)$ & $100.00 \%(n=4)$ & \\
\hline Perineural & Absent & $26.09 \%(n=6)$ & $73.91 \%(n=17)$ & $100.00 \%(n=23)$ & 2 \\
\hline invasion* & Present & $100.00 \%(n=1)$ & $100.00 \%(n=0)$ & $100.00 \%(n=1)$ & 0.292 \\
\hline
\end{tabular}

(1)Chi-square; (2)Fischer exact test. 
Table 4. Histological profile.

\begin{tabular}{|c|c|c|c|}
\hline \multicolumn{2}{|c|}{ Characteristics } & \multirow{2}{*}{$\begin{array}{c}\text { Frequency } \\
22\end{array}$} & \multirow{2}{*}{$\begin{array}{c}\% \\
47.8\end{array}$} \\
\hline \multirow{5}{*}{ Histological type* } & Superficial extensive melanoma & & \\
\hline & Nodular melanoma & 12 & 26.1 \\
\hline & Lentigo malignant melanoma & 5 & 10.9 \\
\hline & Acral-lentiginous melanoma & 5 & 10.9 \\
\hline & Metastatic melanoma & 2 & 4.3 \\
\hline \multirow{4}{*}{ Breslow* } & Until $1.0 \mathrm{~mm}$ & 11 & 28.2 \\
\hline & $1.01-2.0 \mathrm{~mm}$ & 7 & 17.9 \\
\hline & $2.01-4.0 \mathrm{~mm}$ & 10 & 25.6 \\
\hline & Over $4.0 \mathrm{~mm}$ & 11 & 28.2 \\
\hline \multirow{5}{*}{ Clark* } & I & 1 & 2.7 \\
\hline & II & 3 & 8.1 \\
\hline & III & 9 & 24.3 \\
\hline & IV & 18 & 48.7 \\
\hline & V & 6 & 16.2 \\
\hline \multirow{2}{*}{ Ulceration* } & No & 7 & 35.0 \\
\hline & Yes & 13 & 65.0 \\
\hline \multirow{2}{*}{ Angiolymphatic invasion* } & Absent & 20 & 83.3 \\
\hline & Present & 4 & 16.7 \\
\hline \multirow{3}{*}{ Perineural invasion* } & Absent & 23 & 95.8 \\
\hline & Present & 1 & 4.2 \\
\hline & Total & 60 & 100.00 \\
\hline
\end{tabular}

(26.1\%). The thickness of the lesions ranged from 0.1 to $45.0 \mathrm{~mm}$ with an average of 4.3 and a median of 2.5. Most of it presented Breslow lower than $1.0 \mathrm{~mm}(28.2 \%)$ and higher than $4.0 \mathrm{~mm}$ (28.2\%). As for Clark's level, predominated the Clark IV (48.7\%). The ulceration was present in $65.0 \%$ of the lesions, while the angiolymphatic invasion, as well as the perineural were absent in most cases.

In relation to the treatment (Tables 5 and 6), isolated or combined surgery predominated in the study, being indicated for $71.7 \%$ of the patients. The mortality rate was $38.3 \%$. Of these patients, 4 did not die as a result of skin cancer. The mortality rate for melanoma was of $31.7 \%$.

By applying the chi-squared test (X2) or Fischer's exact test on the death rate with the patient's characteristics (Table 3), to a 5\% significance level, there 
is statistical evidence of death with age and stadium, so that patients over the age of 60 years and with advanced stage (III and IV) presented higher mortality rates.

The average mortality time was 688.8 days, with standard deviation of 777.68 , while half of the individuals survived 3.570 days maximum (Figure 1).

Table 5. Treatment.

\begin{tabular}{lcc}
\hline \multicolumn{1}{c}{ Response } & Absolute frequency & $\%$ \\
\hline Surgery & 43 & 71.7 \\
\hline Immunotherapy & 12 & 20.0 \\
\hline Chemotherapy & 11 & 18.3 \\
\hline Radiotherapy & 3 & 5.0 \\
\hline No treatment & 5 & 8.3 \\
\hline Total & 60 & 100.00 \\
\hline
\end{tabular}

Table 6. Condition after first treatment.

\begin{tabular}{lcc}
\multicolumn{1}{c}{ Response } & Absolute frequency & $\%$ \\
\hline Partial remission & 18 & 32.1 \\
\hline Disease in progression & 16 & 28.6 \\
\hline Total remission & 15 & 26.8 \\
\hline Stable disease & 6 & 10.7 \\
\hline Death & 1 & 1.8 \\
\hline Total & 60 & 100.00 \\
\hline
\end{tabular}

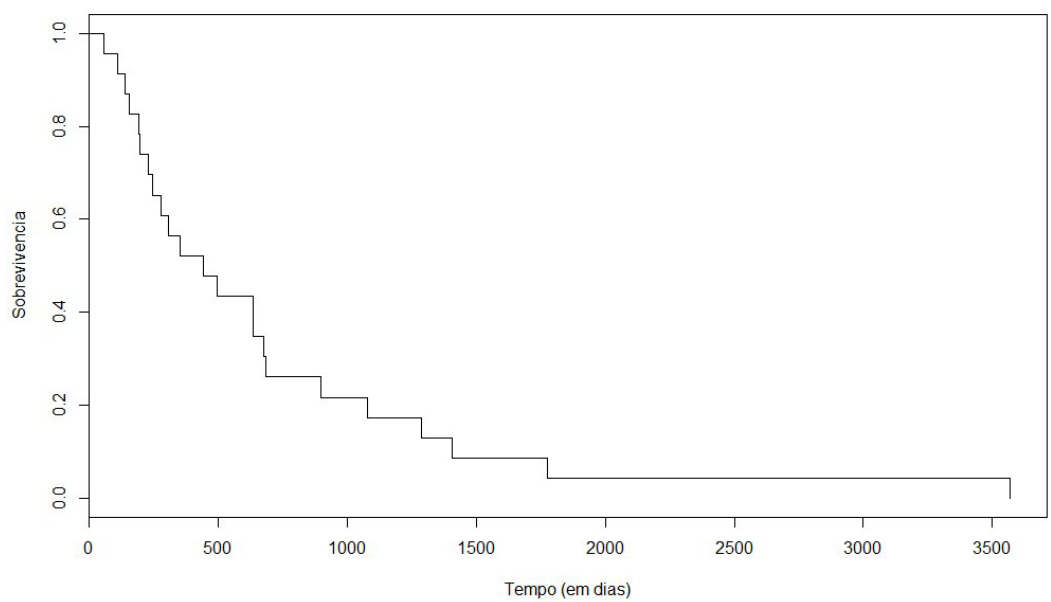

Figure 1. Global life. 


\section{Discussion}

As for gender, most of the patients were women (56.7\%). In most studies there was also female predominance ${ }^{4,5,11}$. According to Brandão et al. ${ }^{4}$, in countries with low incidence of cutaneous melanoma, such as Brazil, female is usually more prevalent.

The age of the patients varied from 15 to 87 years, being the average age 60.4 years. The average age found was slightly higher than other studies, which ranged from 51.1 to 55 years ${ }^{4,11,12}$. Melanoma can affect any age group, being more common in people with more advanced age. This is believed to happen as a result of the cumulative effect of solar radiation and the decline of the immune system ${ }^{12}$.

Most patients were Caucasian (61.0\%). Skin cancer is usually more common in people with phototypes I and II, according to the Fitzpatrick classification ${ }^{13}$. Agriculture was the predominant occupation among patients (38.8\%), which is related to higher solar exposure, the main risk factor, for that kind of worker. Civil and rural construction workers present predisposition to the development of skin cancer of an occupational nature ${ }^{14}$.

The sporadic and chronic exposure to solar radiation provides the onset of skin cancer, with ultraviolet-B (UVB) radiation being the main risk factor for the onset of cutaneous melanoma ${ }^{13}$. However, due to the retrospective and documentary nature of the research, it was not possible to know the habits of the solar exposure of the participants of the research.

Family history is also an important risk factor. Patients with a relative with cutaneous melanoma present a twice-increased risk, while those with three or more relatives present a risk of 35 to 70 times greater ${ }^{4} ; 23.1 \%$ of patients possessed a history of cancer in the family.

Elementary injury was the main complaint of the patients in the first consultation in the hospital (79.3\%). It is important to highlight that $11 \%$ of patients had lymphadenomegaly as main complaint, which means that probably the diagnosis was given after the onset of metastasis lymph node.

The dominant location was the trunk (38.8\%), followed by the lower limbs (32.6\%). Melanomas usually arise in the upper and lower limbs of women and on the torso, head and neck in men. This is related to differences in vesture and lifestyle ${ }^{12,13}$.

Most of the lesions were bigger than $6 \mathrm{~mm}$, however, although the $A B C D$ rule is diameter bigger than $6 \mathrm{~mm}$, it is necessary to be aware of lesions with smaller diameters that encourage early diagnosis ${ }^{11}$.

The stage of skin cancer is best given after histopathological examination of the lesion. It considers various factors such as ulceration, Breslow, mitotic index and metastasis (regional or distant) ${ }^{10}$.

$37.5 \%$ of patients had lymph nodes metastasis. The distant metastasis was present in $28.8 \%$ of the patients, slightly above than found in other studies, being the most part to the lung (33.3\%). Brandão et al. found $40 \%$ of lymph node metastasis and $13.4 \%$ of distant metastasis, being the most common 
site of metastasis the brain ${ }^{4}$. The most common sites of distant metastasis are lung, liver and brain ${ }^{15}$. Predominated the advanced stadium cases (III and IV) (52.6\%), which means late diagnosis.

The predominant histologic subtype was the superficial extensive (47.8\%), followed by nodular (26.1\%), like found in other studies ${ }^{11-13}$. Superficial extensive melanoma is usually the most prevalent and the least aggressive. While the lentiginous-Accra melanoma is the most aggressive, it is also the least common ${ }^{15}$.

Breslow, in 1970, described a system of measurement of the vertical thickness of the lesion in millimeters that presented correlation with the life of patients with skin cancer. The Breslow index, as it is known, is the most efficient predictor in determining the prognosis of a patient with melanoma and is associated with local recurrence and regional and distant metastases.

The thickness of the lesions ranged from 0.1 to $45.0 \mathrm{~mm}$. Most had Breslow smaller than $1.0 \mathrm{~mm}$ (28.2\%) and bigger than $4.0 \mathrm{~mm}$ (28.2\%). The Breslow less than $1 \mathrm{~mm}$ usually predominates in the studies ${ }^{4,15}$.

As for Clark's level, predominated the Clark IV (48.7\%). The level of invasion, as well as the thickness are the most important factors in the prognosis. Level IV means that the lesion has invaded the reticular dermis and is related to a late diagnosis and smaller life time. Overall, levels of Clark III, IV and V and Breslow thickness bigger than $1 \mathrm{~mm}$ are associated with late diagnosis ${ }^{13}$. The Clark I level usually predominates in other studies and the Breslow bigger than $4 \mathrm{~mm}$ has high risk of local recurrence $(10 \text { to } 20 \%)^{4,15}$.

Similarly, ulceration is associated with the increased aggression of the lesion and was reported in $65 \%$ of patients. The angiolymphatic as well as the perineural invasion are considered factors of bad prognosis and were absent in most cases $^{12}$.

The treatment is usually the surgical resection with appropriate margins, with a good cure rate, especially for the initial cases. The surgical modality depends on the extent, aggression and location of the tumor, being the excisional surgery and the Mohs micrographic surgery the most used ${ }^{1}$. The local control of the disease requires ample excision of the lesion to the fascia and a margin of 0.5 to $2 \mathrm{~cm}$, depending on the Breslow. The excision of the lesions should be performed as early as possible, because the treatment of melanoma in its initial phase, requires minor surgeries, in most cases does not need adjuvant therapy and results in higher rate of healing ${ }^{15}$.

In relation to the treatment, in the study, exclusive surgery or combined surgical treatment was the predominant therapeutic modality. As already seen in Table 7, patients who did not had surgery and who had immunotherapy and/or chemotherapy presented more advanced stages, reflecting the indication of chemotherapy and immunotherapy, since surgery itself is unable to provide good oncological outcome.

However, when observing Figure 2, it was realized that the life rates were higher in patients who had adjuvant treatment. Thus, for advanced cases 
Table 7. Tumor stadium versus patient characteristics.

\begin{tabular}{|c|c|c|c|c|c|}
\hline \multirow{2}{*}{\multicolumn{2}{|c|}{ Patient characteristics }} & \multicolumn{2}{|c|}{ Tumor stadium } & \multirow{2}{*}{ Total } & \multirow{2}{*}{ Value-p } \\
\hline & & & & & \\
\hline \multirow{2}{*}{ Gender } & Male & $48.00 \%(n=12)$ & $52.00 \%(n=13)$ & $100.00 \%(n=25)$ & \multirow{2}{*}{$0.933^{(1)}$} \\
\hline & Female & $46.88 \%(n=15)$ & $53.13 \%(n=17)$ & $100.00 \%(n=32)$ & \\
\hline \multirow{2}{*}{ Age group } & Until 60 years & $62.96 \%(n=17)$ & $37.04 \%(n=10)$ & $100.00 \%(n=27)$ & \multirow{2}{*}{$0.025^{(1)}$} \\
\hline & Over 60 years & $33.33 \%(n=10)$ & $66.67 \%(n=20)$ & $100.00 \%(n=30)$ & \\
\hline \multirow{2}{*}{ Family history } & No & $50.00 \%(n=10)$ & $50.00 \%(n=10)$ & $100.00 \%(n=20)$ & \multirow{2}{*}{$0.197^{(2)}$} \\
\hline & Yes & $16.67 \%(n=1)$ & $83.33 \%(n=5)$ & $100.00 \%(n=6)$ & \\
\hline \multirow{2}{*}{ With surgery* } & No & $25.00 \%(n=4)$ & $75.00 \%(n=12)$ & $100.00 \%(n=16)$ & \multirow{2}{*}{$0.035^{(1)}$} \\
\hline & Yes & $56.10 \%(n=23)$ & $43.90 \%(n=18)$ & $100.00 \%(n=41)$ & \\
\hline \multirow{2}{*}{ With immunotherapy* } & No & $57.78 \%(n=26)$ & $42.22 \%(n=19)$ & $100.00 \%(n=45)$ & \multirow{2}{*}{$0.002^{(1)}$} \\
\hline & Yes & $8.33 \%(n=1)$ & $91.67 \%(n=11)$ & $100.00 \%(n=12)$ & \\
\hline \multirow{2}{*}{ With chemotherapy* } & No & $58.70 \%(n=27)$ & $41.30 \%(n=19)$ & $100.00 \%(n=46)$ & \multirow{2}{*}{$0.000^{(1)}$} \\
\hline & Yes & $0.00 \%(n=0)$ & $100.00 \%(n=11)$ & $100.00 \%(n=11)$ & \\
\hline \multirow{4}{*}{ General location* } & Trunk & $66.67 \%(n=12)$ & $33.33 \%(n=6)$ & $100.00 \%(n=18)$ & \multirow{4}{*}{$0.322^{(1)}$} \\
\hline & Inferior limbs & $66.67 \%(n=10)$ & $33.33 \%(n=5)$ & $100.00 \%(n=15)$ & \\
\hline & Head and neck & $44.44 \%(n=4)$ & $55.56 \%(n=5)$ & $100.00 \%(n=9)$ & \\
\hline & Superior limbs & $25.00 \%(n=1)$ & $75.00 \%(n=3)$ & $100.00 \%(n=4)$ & \\
\hline \multirow{4}{*}{ Breslow* } & Until 1 mm & $81.82 \%(n=9)$ & $18.18 \%(n=2)$ & $100.00 \%(n=11)$ & \multirow{4}{*}{$0.473^{(1)}$} \\
\hline & $1.01-2.00 \mathrm{~mm}$ & $57.14 \%(n=4)$ & $42.86 \%(n=3)$ & $100.00 \%(n=7)$ & \\
\hline & $2.01-4,00 \mathrm{~mm}$ & $50.00 \%(n=5)$ & $50.00 \%(n=5)$ & $100.00 \%(n=10)$ & \\
\hline & Over 4,00 mm & $63.64 \%(n=7)$ & $36.36 \%(n=4)$ & $100.00 \%(n=11)$ & \\
\hline \multirow{5}{*}{ Histological type* } & Superficial extensive & $71.43 \%(n=15)$ & $28.57 \%(n=6)$ & $100.00 \%(n=21)$ & \multirow{5}{*}{$0.186^{(1)}$} \\
\hline & Nodular & $50.00 \%(n=6)$ & $50.00 \%(n=6)$ & $100.00 \%(n=10)$ & \\
\hline & Malignant lentigo & $100.00 \%(n=3)$ & $0.00 \%(n=0)$ & $100.00 \%(n=3)$ & \\
\hline & Accra-lentiginous & $40.00 \%(n=2)$ & $60.00 \%(n=3)$ & $100.00 \%(n=5)$ & \\
\hline & Metastatic & $0.00 \%(n=0)$ & $100.00 \%(n=2)$ & $100.00 \%(n=2)$ & \\
\hline \multirow{2}{*}{ Clark* } & I, II and II & $75.00 \%(n=9)$ & $25.00 \%(n=3)$ & $100.00 \%(n=12)$ & \multirow{2}{*}{$0.709^{(2)}$} \\
\hline & IV and V & $62.50 \%(n=15)$ & $37.50 \%(n=9)$ & $100.00 \%(n=24)$ & \\
\hline \multirow{2}{*}{ Ulceration* } & No & $57.14 \%(n=4)$ & $42.86 \%(n=3)$ & $100.00 \%(n=7)$ & \multirow{2}{*}{$0.651^{(2)}$} \\
\hline & Yes & $69.23 \%(n=9)$ & $30.77 \%(n=4)$ & $100.00 \%(n=13)$ & \\
\hline \multirow{2}{*}{ Angiolymphatic invasion* } & Absent & $73.68 \%(n=14)$ & $26.32 \%(n=5)$ & $100.00 \%(n=19)$ & \multirow{2}{*}{$0.103^{(2)}$} \\
\hline & Present & $25.00 \%(n=1)$ & $75.00 \%(n=3)$ & $100.00 \%(n=4)$ & \\
\hline Porinoural invacis & Absent & $68.18 \%(n=15)$ & $31.82 \%(n=7)$ & $100.00 \%(n=22)$ & (2) \\
\hline 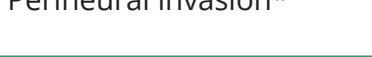 & Present & $0.00 \%(n=0)$ & $100.00 \%(n=1)$ & $100.00 \%(n=1)$ & $0.540^{-12}$ \\
\hline
\end{tabular}

(1)Cui-square; (2)Fischer exact test. 


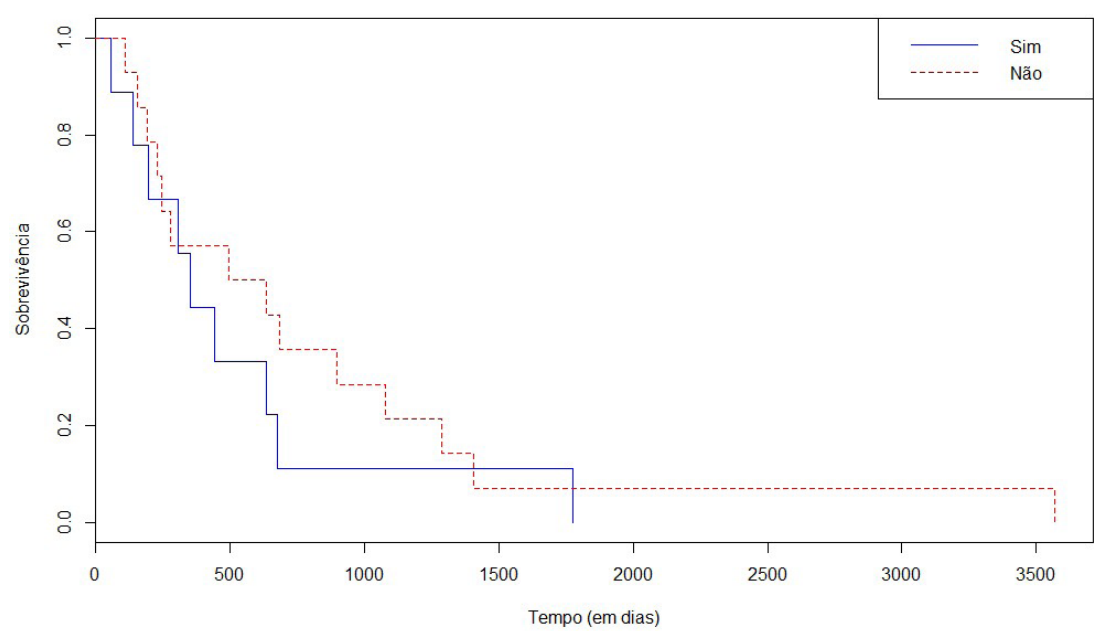

Figure 2. Function of survival of patients treated by surgery.

(most of the study), association of surgery with radiotherapy, chemotherapy and/or immunotherapy showed better survival results.

Melanoma mortality was $31.7 \%$. The average mortality time was 688.8 days, and half of the patients survived at most 3,570 days (Figure 1). It is clear that the likelihood of survival decreases over time.

Thus, prevention is still the best way to decrease the incidence and mortality by melanoma. Primary prevention measures are required: avoid solar exposure, mainly at peak times of ultraviolet radiation, use of sunscreens and physical measurements such as hats. Secondary prevention can be done by clarifying the population regarding the signs of melanoma and training of health professionals, so that the diagnosis can be as early as possible ${ }^{16}$.

The profiles found were similar to those of other departments, according to the literature, except for the age variables, whose average was higher in this study, and the level of Clark, which was also higher than in other works.

High mortality and high index of patients in advanced stages indicate late diagnosis, reflecting the need for preventive actions, training of health professionals to identify early injuries and improvement in access to the health system.

\section{Conclusion}

The patients with melanoma served in COHM are mostly women in the sixth decade of life, Caucasian, with incomplete elementary school, farmers, with no family history of cancer and who arrive at the hospital reporting an elementary trunk injury in advanced stadium. The lesion, predominantly of the superficial extensive melanoma type, had Breslow below $1 \mathrm{~mm}$ or above $4 \mathrm{~mm}$, Clark IV, with ulceration, but without angiolymphatic or perineural invasion. The predominant treatment was the surgical, associated or not to an adjuvant therapy. 


\section{Acknowledgements}

We thank the COHM for the opportunity of scientific initiation, availability of the study material, as well as structure and support for the development of the project.

\section{References}

1. Sociedade Brasileira de Dermatologia. Câncer de pele. Rio de Janeiro: SBD; 2016.

2. Aquilina S, Dalmas M, Calleja N, Gatt P, Scerri L. A profile of invasive cutaneous malignant melanoma in Malta: 1993-2002. J Eur Acad Dermatol Venereol. 2006;20(8):958-63. PMid:16922945.

3. Instituto Nacional do Câncer. Tipos de câncer: pele melanoma. Rio de Janeiro: INCA; 2016.

4. Brandão FV, Pereira AF, Gontijo B, Bittencourt FV. Epidemiological aspects of melanoma at a university hospital dermatology center over a period of 20 years. An Bras Dermatol. 2013;88(3):344-53. http://dx.doi.org/10.1590/abd18064841.20131855. PMid:23793193.

5. Lima AS, Stein CE, Casemiro KP, Rovere RK. Epidemiology of melanoma in the South of Brazil: study of a city in the Vale do Itajaí from 1999 to 2013. An Bras Dermatol. 2015;90(2):185-9. http://dx.doi.org/10.1590/abd1806-4841.20153076. PMid:25830987.

6. Iranzo CC, Rubia-Orti JE, Castillo SS, Firmino-Canhoto J. Lesões cutâneas malignas e pré-malignas: conhecimentos, hábitos e campanhas de prevenção solar. Acta Paul Enferm. 2015;28(1):2-6. http://dx.doi.org/10.1590/1982-0194201500002.

7. Bakos RM, Besch R, Zoratto GG, Godinho JM, Mazzotti NG, Ruzicka T, Bakos L, Santos SE, Ashton-Prolla P, Berking C, Giugliani R. The CDKN2A p.A148T variant is associated with cutaneous melanoma in Southern Brazil. Exp Dermatol. 2011;20(11):890-3. http://dx.doi.org/10.1111/j.1600-0625.2011.01332.x. PMid:21895773.

8. Brehmer F, Ulrich M, Haenssle HA, Haenssle HA. Strategies for early recognition of cutaneous melanoma: present and future. Dermatol Pract Concept. 2012;2(3):a06. http://dx.doi.org/10.5826/dpc.0203a06. PMid:23785608.

9. Ribeiro AMQ. Fatores prognósticos de melanoma cutâneo em um estudo de base populacional em Goiânia [tese]. Brasília: Universidade de Brasília; 2008.

10. Instituto Nacional do Câncer. TNM: classificação de tumores malignos. Rio de Janeiro: INCA; 2004.

11. Oliveira RS Fo, Oliveira DA, Souza MC, Silva M, Brandão MDC. Suspected melanoma only when the lesion is greater than $6 \mathrm{~mm}$ may harm patients. Einstein. 2015;13(4):506-9. http://dx.doi.org/10.1590/S1679-45082015A03436. PMid:26761547.

12. Battisti R, Nunes DH, Weber AL, Schweitzer LC, Sgrott I. Avaliação do perfil epidemiológico e da mortalidade dos pacientes com diagnóstico de melanoma cutâneo primário no município de Florianópolis - SC, Brasil. An Bras Dermatol. 2009;84(4):335-42. http://dx.doi.org/10.1590/S0365-05962009000400003. PMid:19851664. 


\section{*Correspondence}

Thiago Demétrio Nogueira Costa e Silva

Universidade Federal Rural do

Semi-Árido (UFERSA)

Rua Francisco Mota, 572 - Pres. Costa

e Silva

CEP 59625-900, Mossoró, RN, Brasil

Tel.: +55 (84) 33178263

E-mail: dr.tdemetrio@yahoo.com

\section{Authors information}

TDNCS - Effective Professor, Federal Rural University of Semi-Arid. ERRSO,

SMCC and CISC - Medicine Student, FACS, UERN; KRFB - Nurse coordinator of the registry hospital of the Mossoro League of Studies and Fight against Cancer.
13. Naser N. Melanoma cutâneo: estudo epidemiológico de 30 anos em cidade do sul do Brasil, de 1980-2009. An Bras Dermatol. 2011;86(5):932-41. http://dx.doi. org/10.1590/S0365-05962011000500011. PMid:22147033.

14. Matheus LGM, Verri BHM. Aspectos epidemiológicos do melanoma cutâneo. RCEAM. 2015;3:10-24.

15. Dimatos DC, Duarte FO, Machado RS, Vieira JV, Vasconcellos ZAA, Bins-Ely J, Neves RD. Melanoma cutâneo no Brasil. Arq Cat Med. 2009;38:S14-9.

16. Salvio AG, Assumpção AA Jr, Segalla JG, Panfilo BL, Nicolini HR, Didone R. Experiência de um ano de modelo de programa de prevenção contínua do melanoma na cidade de Jaú-SP, Brasil. An Bras Dermatol. 2011;86(4):669-74. http://dx.doi.org/10.1590/S0365-05962011000400007. PMid:21987131. 